\title{
Molecular Effects and Antibacterial Activities of Ginger Extracts against Some Drug Resistant Pathogenic Bacteria
}

\author{
Attiya Mohamedin", Ashraf Elsayed and Fathi Abdallah Shakurfow* \\ Botany Department, Faculty of Science, Mansoura University, Dakahlia, Egypt \\ and "Medical Microbiology Department, Faculty of Medical Technology, El-Mergib \\ University, Libya.
}

\begin{abstract}
N THIS study, the antibacterial activity of six types of ginger extracts was evaluated against drug resistant E. coli, Shigella dysenteriae, Staphylococcus aureus and Staphylococcus epidermidis. The impact of ginger methanol extract on the tested bacteria was studied at the molecular level via SDS-PAGE and RAPD-PCR methods. From the six types of ginger extracts, ginger methanol extract recorded a remarkable antimicrobial activity and the minimum inhibitory concentration was $0.7 \mathrm{mg} / \mathrm{ml}$ against all tested bacteria. The Gram positive bacteria showed more sensitivity to ginger methanol extract and lower growth rate pattern than the Gram negative bacteria. The qualitative phytochemical analysis of ginger methanol extract recorded the presence of steroids and flavonoids that are wide-range antimicrobial agents. From GC-MS results, sixteen compounds were identified with major compounds gingerol $(30.56 \%)$, cis-6-shagol (21.61\%), zingerone (8.22\%) and 2,4-dimethyl- Benzo[h]quinolone (5.48\%). The combination of ginger methanol extract with gentamycin or amoxicillin antibiotics improved its antibacterial activity. The biomarker assay detecting the protein changes based on SDSPAGE profile and the genetic changes based on RAPD-PCR manipulation of ginger methanol extract manifested a polymorphic pattern when treated and untreated bacteria were compared. In conclusion, the application of ginger methanol extract increased the activity of gentamycin and amoxicillin antibiotics and because ginger methanol extract has effective and safe bioactive antimicrobial agent against Gram positive and Gram negative bacteria, it can be used as an alternative drug.
\end{abstract}

Keywords: GC-MS, Ginger extracts, Bacteria, Protein, RAPD-PCR.

\section{Introduction}

Searching for new antibacterial agents from natural sources was enforced by the emergence of antibiotic resistant bacteria due to the indiscriminate use of antibiotics (Abiramasundari et al., 2011). Medicinal plants might be in that focus because they are rich with gingerols, Zingerone, shogaols and other bioactive compounds which belong to different classes such as tannins, alkaloids, carbohydrates, terpenoids, steroids and flavonoids (Yadav \& Agarwala, 2011).

Since long time, ginger (Zingiber officinale) is one of largely used spices which has been used in conventional orintal medicins as anticancer (Wang et al., 2002 and Wei et al., 2005), antiinflammatory (Habib et al., 2008), antimicrobial and antifungal agent (Park et al., 2008). Fresh ginger has been used for treatment of nausea, cold-induced disease, colic, asthma, cough, heart palpitation, swellings, dyspepsia, loss of appetency, and rheumatism (Wichtl, 2004). $Z$. officinale is an herbaceous perennial plant belonging to the family Zingiberaceae and has phenolic compounds such as gingerols (gingerolrelated compounds), shogaols, sesquiterpenes and zingiberenes. The major pungent components of ginger are 6-gingerol and 6-paradol. Ginger rhizome also contains diarylheptanoids which have different shapes such as a linear shaped curcumin and a cyclic shaped myricanone (Park et al., 2008; Nazari et al., 2015 and Arshad \& Shadab, 2017).

Ginger extracts have different degrees of antibacterial potentiality (Wei et al., 2005 and Arshad \& Shadab, 2017), where the essential oil of ginger was stronger than the oleoresin against $E$. coli and $S$. aureus (Bellik, 2014). Ginger aqueous extract has weak effect on E. coli, Pseudomonas aeruginosa, Bacillus subtilis, Staphylococcus 
epidermidis, S. aureus, Klebsiella pneumoniae, Shigella sonnei, and Salmonella typhi (Gull et al., 2012), where as the antimicrobial effects of ginger extract in peptone water buffer against $E$. coli O157:H7 was strong (Gupta \& Ravishankar, 2005). On the other hand, some bacterial strains such as Salmonella enterica serotype, Typhimurium and E. coli O157: H7 were resistant to ethanol ginger extract (Pattaratanawadee et al., 2006).

The hugeuse of antibiotics have developed multiple drug resistance (MDR) of many pathogenic bacteria (Pattaratanawadee et al., 2006). This study aimed to investigate the antibacterial activity of ginger extracts and identify the compounds of the most active ginger extract (ginger methanol extract) by GC-MS analysis, and also to evaluate the synergistic effect of ginger methanol extract with amoxicillin and gentamicin antibiotics. In addition, the impact of ginger methanol extract on the four tested pathogenic bacteria (E. coli, Shigella. dysenteriae, Staphlococcus aureus and S. epidermidis) was performed at the molecular level.

\section{Materials and Methods}

\section{Plant material}

Ginger rhizome powder was purchased from local Egyptian market and stored in dry condition at room temperature.

\section{Tested bacteria}

Four different characterized drug resistant bacterial strains including $E$. coli and $S$. dysenteriae (Gram negative), $S$. aureus and $S$. epidermidis (Gram positive), were used in this study. The strains were preserved on LB agar medium at $4^{\circ} \mathrm{C}$ and were sub-cultured at $37^{\circ} \mathrm{C}$ for $24 \mathrm{~h}$ every month. These organisms were originally obtained from the culture collection of Department of Microbiology and Immunology, Faculty of Medicine, Mansoura University, Egypt.

\section{Preparation of ginger extracts}

The method of Gull et al. (2012) was used for the preparation of ginger extracts. The ginger powder $(10 \mathrm{~g})$ was extracted with $100 \mathrm{ml}$ of each organic solvent (water, methanol, ethanol, acetone, chloroform and petroleum ether) separately for 3 days at room temperature. All types of extracts were filtered with filter papers and then dried in oven at $40^{\circ} \mathrm{C}$ except water extract which was dried at $80^{\circ} \mathrm{C}$. Oven-dry extracts were dissolved in $10 \%$ Dimethyl sulphoxide (DMSO) with a final concentration $3 \mathrm{mg} / \mathrm{ml}$.
Antibacterial bioassay of ginger extracts using disc diffusion method

To evaluate the antibacterial activity of the six types of ginger extracts, the disc agar diffusion method was used as described by Bhargava et al. (2012). LB agar plates were inoculated separately with $10^{7} \mathrm{CFU}$ of every bacterial strain culture and regularly spread on whole surface of each plate. The $5 \mathrm{~mm}$ diameter sterile discs were saturated with $10 \mu \mathrm{l}$ of the different extracts and placedon LB plates inoculated with bacterial culture. The plates were incubated for $24 \mathrm{~h}$ at $37^{\circ} \mathrm{C}$ and observed for zone of inhibition. The diameter of inhibition zones were measured in millimeters. $10 \%$ DMSO was used as negative controls and standard reference antibiotics; gentamycin $(10 \mu \mathrm{g} /$ disc) and amoxicillin (30 $\mu \mathrm{g} / \mathrm{disc})$ were used as positive controls for the tested bacteria. Each assay in this test was done in three replicates.

\section{Statistical analysis}

Each experiment was run in triplicate, and mean values were calculated. The statistical analysis was carried out employing one way ANOVA $(p<0.01)$. A statistical package (SPSS version 16.0) was used for data analysis.

\section{Determination of MIC of ginger methanol extract (GiM)}

MIC of ginger extract was determined using disc agar diffusion method as described by Bhargava et al. (2012). Serial dilutions of ginger methanol extract were prepared to obtain concentrations of $0.35,0.7,1.4$ and $2.8 \mathrm{mg} /$ $\mathrm{ml}$ and tested for MIC against bacterial strains. Sterile filter paper discs were saturated with 10 $\mu l$ of the different dilutions of ginger extract and placed on LB agar plates inoculated with $10^{7} \mathrm{CFU}$ of bacterial cultures separately. Plates were placed at $37^{\circ} \mathrm{C}$ for $24 \mathrm{~h}$. The zone of inhibition in each case was measured as the diameter of the clearing zones and the results were documented. Each test was performed in three replicates.

\section{Phytochemical and GC-MS analysis of ginger methanol extract}

Qualtitive phytochemical screening was carried out on GiM. The extract was tested for the presence of bioactive compounds such as terpenoids, glycosides, flavonoids, coumarins, alkaloids compounds, tannins, and saponins by using standard methods of Yadav \& Agarwala (2011). GiM extract sample was injected in Agilent GC-MS equipment under certain conditions. Wiley and Wiley Nist mass spectral data base was 
used in the identification of the spectral peaks, GC-MS was carried out at Central Agricultural Pesticide Laboratory (CAPL), Giza, Egypt.

\section{Influence of ginger methanol extract on bacterial growth}

Turbidity method

Influence of GiM extract on the tested bacteria was evaluated by culturing in LB broth media containing the measured MIC value for bacterial strains $(0.7 \mathrm{mg} / \mathrm{ml})$ as a final concentration. LB broth media were inoculated with inoculum size of $10^{6} \mathrm{CFU} / \mathrm{ml}$ of each bacterial strain and the inoculated media was incubated in the incubation shaker $\left(37^{\circ} \mathrm{C}, 150 \mathrm{rpm}\right)$. The growth of bacteria was determined by measuring the optical density of the culture at $600 \mathrm{~nm}$ every $2 \mathrm{~h}$ and up to 6 husing UV-visible spectrophotometer. The culture without extract was used as control (Elazomi et al., 2016).

\section{Viable count method}

For viable count method, each of the tubes inoculating with bacterial suspension (approximately $5.0 \times 10^{4} \mathrm{CFU} / \mathrm{ml}$ ) of each bacterial strain in LB broth medium was inoculated with MIC concentration in $50 \mathrm{ml} \mathrm{LB}$ broth, and kept at $37^{\circ} \mathrm{C}$ for overnight. The cultures were diluted several times $\left(10^{-1}, 10^{-2}, 10^{-3}\right.$, and $\left.10^{-4}\right)$ in LB broth media and $100 \mu$ of each dilution was inoculated on LB agar plate. The viable count was recorded as colony forming units per $\mathrm{ml}$ $(\mathrm{CFU} / \mathrm{ml})$, after incubation at $37^{\circ} \mathrm{C}$ for $24 \mathrm{~h}$. The controls were inoculated without ginger extract for each bacterial strain with the same conditions as mentioned above. For counting, only plates that contained a number of colonies ranging from 30 to 300 were selected (Lawal et al., 2015).

\section{Synergistic effect of GiM extract with antibiotics}

Single impact of GiM extract, amoxicillin (AX) and gentamicin (GM) as well as combinations of $\mathrm{AX}+\mathrm{GiM}$ and $\mathrm{GM}+\mathrm{GiM}$ were performed. Commercially antibacterial AX discs $(30 \mu \mathrm{g})$ and GM discs $(10 \mu \mathrm{g})$ were saturated with $10 \mu \mathrm{l}$ GiM extract $(0.7 \mathrm{mg} / \mathrm{ml})$ under aseptic conditions and then were applied on the surface of LB agar media freshly inoculated by the tested bacteria. The plates were incubated at $4^{\circ} \mathrm{C}$ for $20 \mathrm{~min}$ and then were transferred to $37^{\circ} \mathrm{C}$ for $24 \mathrm{~h}$. After the incubation period, the diameters of the inhibition zones formed were measured in $\mathrm{mm}$ and then compared with each other (Hudzicki, 2009).

\section{$S D S-P A G E$}

The four tested bacteria treated with GiM and untreated (control) were cultured in LB broth media at $37^{\circ} \mathrm{C}$ for $24 \mathrm{~h}$. The bacterial cells were harvested by centrifugation at $10.000 \mathrm{rpm}$ for 5 min. The pellets were homogenized in phosphate buffer (0.6 M, pH 6.8) using glass beads and FastPrep ${ }^{\circledR}-24$ homogenizer and then centrifuged at $10.000 \mathrm{rpm}$ for $5 \mathrm{~min}$. Ten $\mu 1$ protein samples from each bacteria were boiled with $30 \mu \mathrm{l}$ of $2 \mathrm{X}$ sample buffer (10 ml Distilled Water, $2.5 \mathrm{ml}$ Tris$\mathrm{HCl} \mathrm{pH}$ 6.8, $2 \mathrm{ml}$ Glycerol, $4 \mathrm{ml}$ of 10\% SDS and $1 \mathrm{ml} \beta$ - mercaptoethanol) for $2 \mathrm{~min}$, cooled immediately on ice and $20 \mu \mathrm{l}$ of lysed cell product were loaded over acrylamide gel. Acrylamide gel was prepared according to Laemmli (1970) from two layers; $4 \%$ stacking gel on top of $12 \%$ separating gel. After electrophoresis at $100 \mathrm{~V}$ for $2 \mathrm{~h}$, gel was overnight stained in Commassie brilliant blue R250 and visualized by soaking in destaining solution on shaker for some hours. The gel was documented and analysed using gel analyser 3 programme.

\section{$R A P D-P C R$}

The four tested bacteria were cultured in LB broth media provided with the MIC of GiM extract at $37^{\circ} \mathrm{C}$ for overnight. The genomic DNA was isolated from the bacterial pellets according to the instructions of GeneJET Genomic DNA purification Kit (Thermo scientific, Germany). The purified DNA was used as a template RAPD-PCR reaction using three primers (U16-25-5.CTGCGCTGGA3, T16-25-5.GGTGAACGCT3, and K02-255,GTCTCCGCAA3'). The reaction mixture was adjusted with a total volume of $20 \mu \mathrm{l}: 1 \mu \mathrm{l}$ DNA template, $4 \mu \mathrm{l} 5 \mathrm{x}$ master-mix buffer, $2 \mu \mathrm{l}$ primer, $0.5 \mu \mathrm{l}$ Taq DNA polymerase and 12.5 $\mu l$ distillate water. The PCR program was: $94^{\circ} \mathrm{C}$ for $3 \mathrm{~min}, 94^{\circ} \mathrm{C}$ for $1 \mathrm{~min}, 30^{\circ} \mathrm{C}$ for $30 \mathrm{sec}, 72^{\circ} \mathrm{C}$ for $1 \mathrm{~min}, 72^{\circ} \mathrm{C}$ for $5 \mathrm{~min}$ ( 40 cycles). The PCR products were detected on $1.2 \%$ agarose gel by gel documentation system (Nippon Genetics Company), followed by introducing to Gel Analyser program 3 for analysis.

\section{Results}

The antibacterial activity of ginger extracts

The antimicrobial activity of the six types of ginger extracts were measured as inhibition zones $(\mathrm{mm})$ against the four tested pathogenic bacteria (Fig. 1). The results indicated that different ginger extracts had a widerange antibacterial activity with different degrees of sensitivity of tested pathogenic bacteria. Growth inhibition was not observed around the control disc containing 
DMSO. Fig. 1 shows that ginger water extract $(\mathrm{GiW})$, ginger ethanol extract (GiE) and ginger petroleum ether extract (GiP) had no effect on $S$. dysenteriae, E. coli and $S$. aureus, respectively. On the other hand various extracts of ginger affected the growth of the tested pathogenic bacteria with variable degrees of inhibition zones. Ginger methanol extract (GiM), ginger acetone extract (GiA) and ginger chloroform extract (GiC) showed variable inhibition zones ranging from (6-12 $\mathrm{mm}$ ) on all tested pathogenic bacteria. The results also showed that Gram positive and Gram negative bacteria were sensitive to most of the extracts of ginger, however Gram positive bacteria were more sensitive than Gram negative bacteria. S. epidermidis was affected by the six types of ginger extracts more than the other tested bacteria. GiM extract recorded wide broad spectrum antimicrobial activity. Therefore ginger methanol extract was selected for further studies.

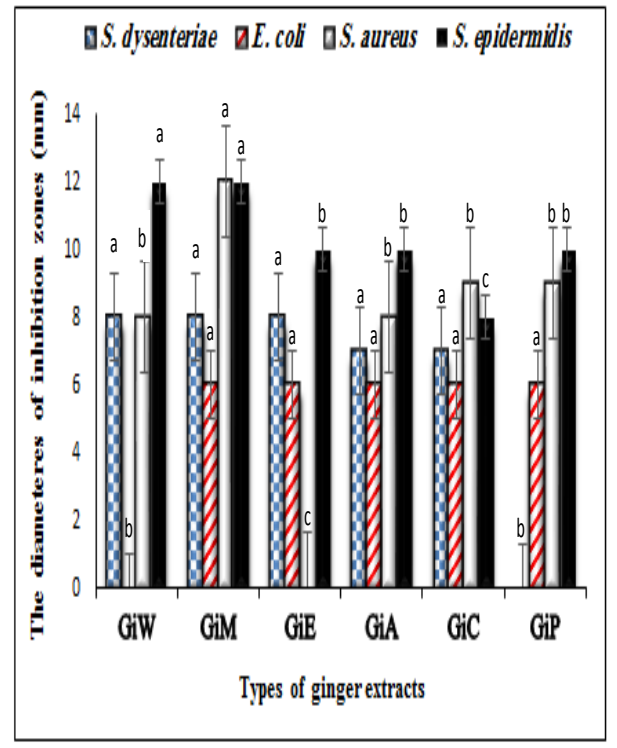

Fig. 1. Mean of inhibition zone ( $\mathrm{mm})$ of 6 types of medicinal plant extracts from ginger against four drug resistant pathogenic bacteria $S$. dysenteriae, E. coli, $S$. aureus and $S$. epidermidis using disc agar diffusion method.

(GiW; ginger water extract, GiM; ginger methanol extract, GiE; ginger ethanol extract, GiA; ginger acetone extract, GiC; ginger chloroform extract, GiP; ginger petroleum ether extract); Data are the means of three replicates and errors bars represent the standard errors of the means. Means within the same bacteria denoted with different letters are significantly different at $\mathbf{p}<\mathbf{0 . 0 1}$

\section{The MIC of GiM extract}

The results showed that the MIC of ginger methanol extract (GiM) was $0.7 \mathrm{mg} / \mathrm{ml}$ with all of the tested bacteria.

Phytochemical screening and GC-MS analysis of GiM extract

The qualitative phytochemical analysis of methanol extract of ginger showed the presence of triterpenes, carbohydrates, flavonoids, alkaloid compounds, tannins and saponins. Table 1 showed the GC-MS profile of GiM extract and the relative amount of each compound. Sixteen compounds from GiM extract were identified with major substances gingerol (30.56\%), cis-6-shagol (21.61\%), zingerone $(8.22 \%)$ and 2,4-dimethylBenzo[h]quinolone (5.48\%).

Effect of GiM extract on the growth of the tested bacteria

\section{Growth curve analysis}

The comparison of the growth patterns of treated bacteria with GiM and untreated (Fig. 2) showed that, the growth of the four untreated bacteria increased with different rates during the whole incubation period. The rate of growth of $S$. aureus and $S$. dysenteriae in absence of GiM extract was better than $E$. coli and $S$. epidermidis. On the other hand, the growth of all bacteria was inhibited by GiM treatment. Gram positive bacteria $S$. aureus and $S$. epidermidis were more sensitive to GiM extract than Gram negative bacteria S. dysenteriae and E. coli.

\section{Bacterial viable count analysis}

The viable count of the four tested bacteria recorded reduction of differed degrees under the effect of the MIC of GiM extract (Table 2). The maximum reduction $86.8 \%$ appeared with $S$. epidermidis, while the minimum reduction $51.7 \%$ appeared with S. dysenteriae. In between, E. coli recorded growth inhibition $66.1 \%$ and $S$. aureus recorded growth inhibition $79.6 \%$.

The synergistic effect of GiM extract with antibiotics

Single impact of GiM extract showed a maximum inhibition zone $(12 \mathrm{~mm})$ on $S$. aureus. While, both amoxicillin (AX) and gentamycin (GM) separately recorded a maximum inhibition zone of 18 and $27 \mathrm{~mm}$, respectively against E. coli. Combination of GiM extract and AX maximized the activity of AX by $22.2 \%$ against S. epidermidis. Also combination of GiM extract with GM maximized the activity of inhibition of GM by $27.6 \%$ against $S$. dysenteriae (Fig. 3). 
TABLE 1. GC-MS analytical results of ginger methanol extract.

\begin{tabular}{cclc}
\hline No & Retention time $(\mathbf{m i n})$ & \multicolumn{1}{c}{ Compounds } & Area (\%) \\
\hline 1 & 6.196 & Isometric dihydro-metyl-furanone & 1.57 \\
2 & 11.605 & 3,5-Dihydroxy-6-methyl-2,3-dihydro-4H-pyran-4-one & 3.94 \\
3 & 16.228 & 2-Methoxy-4-vinylphenol & 1.30 \\
4 & 18.423 & 4-hydroxy-3-methoxy Benzaldehyde & 4.54 \\
5 & 24.397 & Zingerone & 8.22 \\
6 & 27.873 & 3-Oplopenone & 4.78 \\
7 & 28.059 & 1-Ethylideneoctahydro-7a-methyl-1H-iodene & 3.01 \\
8 & 29.270 & Cychlohexandecane & 3.99 \\
9 & 35.686 & 6-Amino-2,4-dimetylphenol & 0.77 \\
10 & 36.874 & Cis-6-shogaol & 21.61 \\
11 & 38.475 & Gingerol & 30.56 \\
12 & 39.383 & Octadecanoic acid & 1.68 \\
13 & 40.245 & Capsaicin & 2.26 \\
14 & 40.973 & Benzene di-carboxylic acid & 3.87 \\
15 & 43.418 & 2-[4-Chlorophynyl]-5-pyrimidinamin; & 2.42 \\
16 & 50.719 & 2,4-dimethyl- Benzo[h]quinolone & 5.48 \\
\hline
\end{tabular}
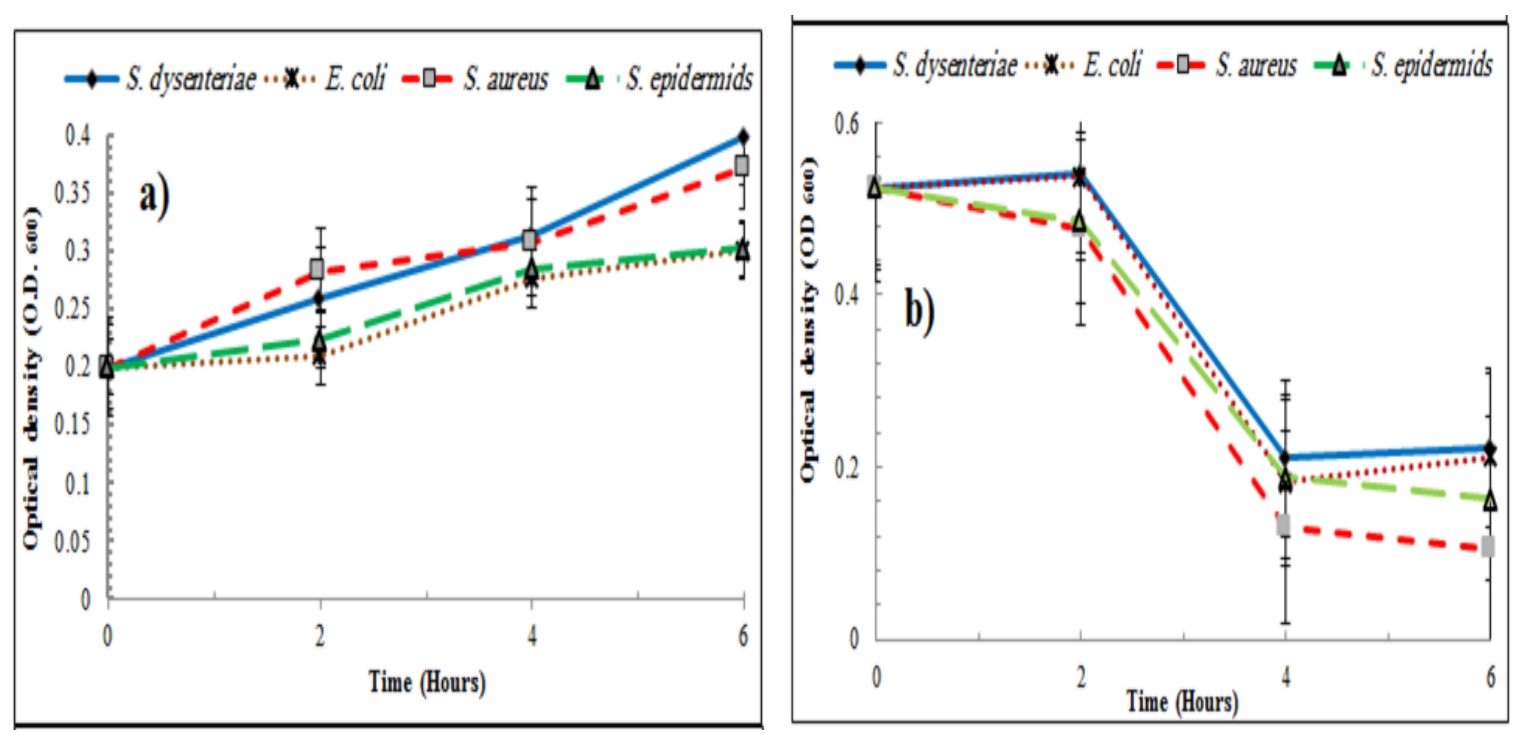

Fig. 2. The growth curve (OD 600); a) Untreated bacteria (control) and b) Treated bacteria (by MIC value of GiM). S. dysenteriae, E. coli, S. aureus and S. epidermidis bacterial cultured in LB broth media. Data are the means of three replicates and errors bars represente the standard errors of the means.

TABLE 2. Viable count and percent of bacterial growth inhibition of pathogenic bacteria untreated (control) and treated with the MIC value of ginger methanol extract.

\begin{tabular}{lcccc}
\hline Types of bacteria & $\mathbf{0 . 0 ~ \mathbf { ~ h }}$ & Untreated, 24 h & Treated, 24 h & $\begin{array}{c}\text { Bacterial growth } \\
\text { inhibition (\%) }\end{array}$ \\
\hline S. dysenteriae & $5.0 \times 10^{4}$ & $5.8 \times 10^{8}$ & $2.8 \times 10^{8}$ & $51.7 \%$ \\
E. coli & $5.1 \times 10^{4}$ & $5.9 \times 10^{8}$ & $2.0 \times 10^{8}$ & $66.1 \%$ \\
S. aureus & $5.6 \times 10^{4}$ & $6.4 \times 10^{8}$ & $1.3 \times 10^{8}$ & $79.6 \%$ \\
S. epidermidis & $5.3 \times 10^{4}$ & $6.1 \times 10^{8}$ & $1.4 \times 10^{8}$ & $86.8 \%$ \\
\hline
\end{tabular}




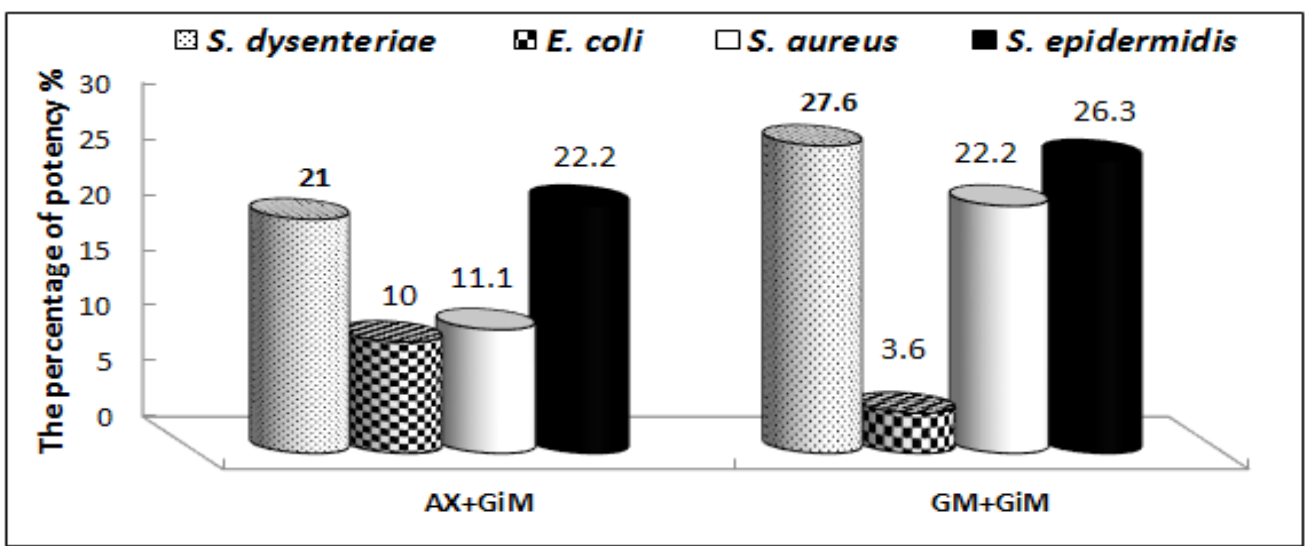

Fig. 3. The increasing of antibiotic activity of combination $\mathrm{AX}+\mathrm{GiM}$ and $\mathrm{GM}+\mathrm{GiM}$ against $\boldsymbol{S}$. dysenteriae, E. coli, $S$. aureus and $S$. epidermidis as expressed by the increasing in inhibition zone diameter (AX+GiM; amoxicillin + ginger methanol extract; GM+GiM; gentamycin + ginger methanol extract).

Effect of GiM extract on the protein pattern of the tested bacteria

Protein profile of the four tested bacteria treated with GiM extract was documented in Fig. 4 and Table 3. In case of $S$. dysenteriae, the total protein bands were 40 , distributed as 34 monomorphic and 6 polymorphic bands. In case of $E$. coli, the total bands were 36 bands, distributed as 32 monomorphic bands and polymorphic bands. In case of $S$. aureus, the total bands were 38 bands distributed as 28 monomorphic and 10 polymorphic bands. In case of $S$. epidermidis, the total bands were 40 bands distributed as; 38 monomorphic and 2 polymorphic bands. The highest percentageof polymorphism was obtained with $S$. aureus $(26.3 \%)$ and the lowest percentage of polymorphism was obtained with $S$. epidermidis $(5.0 \%)$.

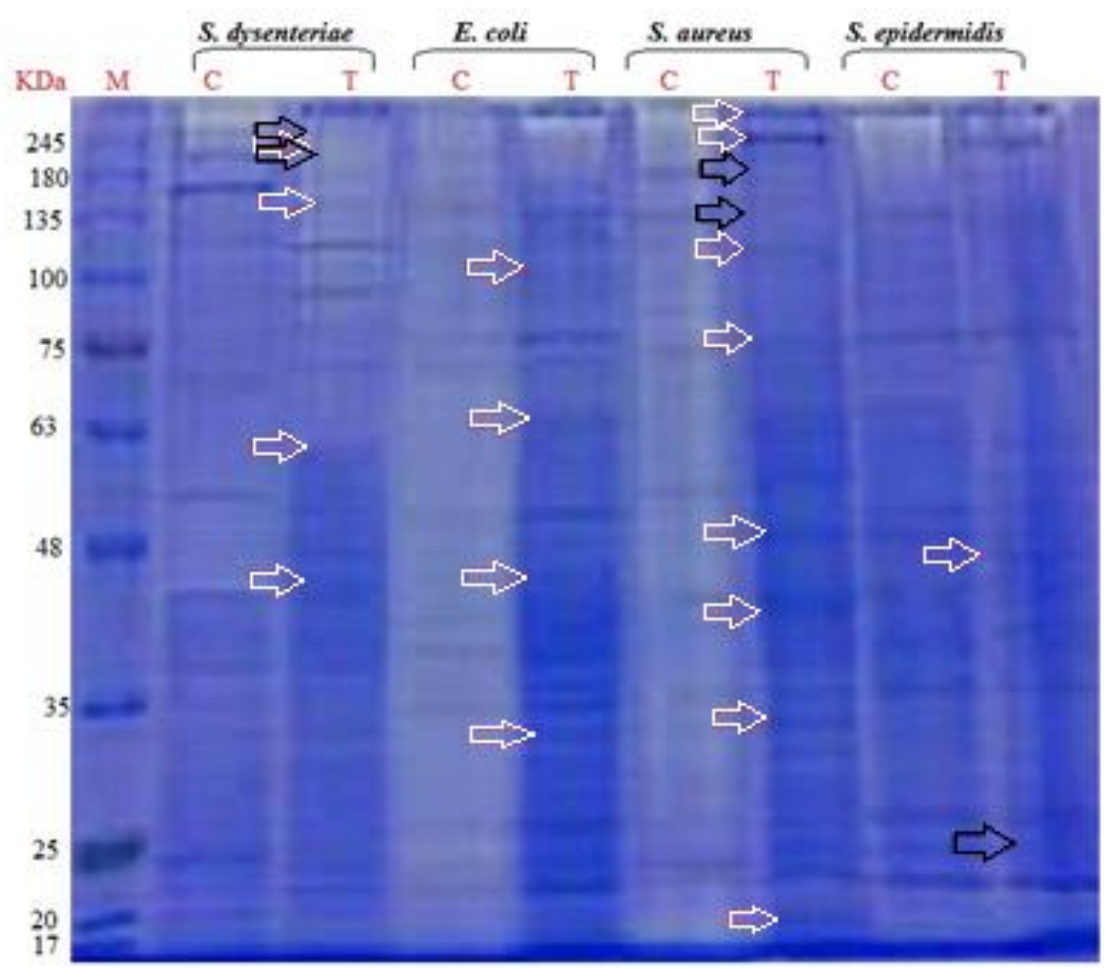

Fig. 4. Protein pattern of $S$. dysenteriae, E. coli, S. aureus and S. epidermidis bacteria cultivated on LB broth media provided with $\mathrm{GiM}$ extract; $\mathrm{KDa}=$ Kilo Dalton, $\mathrm{M}=$ marker, $\mathrm{C}=$ control; untreated bacteria, $\mathrm{T}=$ treated bacteria with GiM extract, black arrow= disappeared band, white arrow= new band. 
TABLE 3. Comparative analysis of relative protein band percentages of $S$. dysenteriae, $E$. coli, $S$. aureus and $S$. epidermidis bacteria, treated with the MIC of ginger methanol extractfor $24 \mathrm{~h}$ and untreated bacteria by using SDS-PAGE technique.

\begin{tabular}{lcccc}
\hline & Bacteria & S. coli & S. aureus & S. epidermidis \\
No. of Bands & 19 & 16 & 16 & 21 \\
\hline Control & 21 & 20 & 22 & 19 \\
Treated & $34(85.0)$ & $32(89.0)$ & $28(73.7)$ & $38(95.0)$ \\
Monomorphic No. (\%) & $6(15.0)$ & $4(11.0)$ & $10(26.3)$ & $2(5.0)$ \\
Polymorphic No. (\%) & 40 & 36 & 38 & 40 \\
Total No. & & &
\end{tabular}

Effect of GiM extract on DNA of pathogenic bacteria

The stability of the bacterial genomic DNA after the treatment with the GiM extract was evaluated with using RAPD analysis. The RAPD results illustrated in Table 4 and Fig. 5., show polymorphic numbers and percentage of the genetic bands, which were the electrophoretic yields of PCR for treated bacteria compared with those of untreated bacteria. Table 4 demonstrates that highest total number of polymorphic bands among treated $S$. dysenteriae was obtained in reactions with primers $\mathrm{T} 16-25$ and $\mathrm{K} 02-25$ which were 10 and 6 , respectively of genetic bands and represented 83.3 and $100 \%$, respectively of total bands. While, the highest number among treated $E$. coli was obtained in reactions with primers U16-25 and K02-25 which was 5 and 4 genetic bands, respectively and represented 45.5 and $100 \%$, respectively of total bands. But, the highest number among $S$. aureus and $S$. epidermidis was obtained with all primers.

TABLE 4. Comparative analysis of relative DNA band percentages of $S$. dysenteriae, $E$. coli, $S$. aureus and $S$. epidermidis bacteria, treated with the MIC of GiM extract for $24 \mathrm{~h}$ and untreated bacteria by using three DNA-primers; a) U16-25, b) T16-25 and c) K02-25.

\begin{tabular}{|c|c|c|c|c|c|c|c|c|c|c|c|c|c|}
\hline \multirow{2}{*}{$\begin{array}{l}\text { No. of } \\
\text { bands }\end{array}$} & \multicolumn{2}{|l|}{ Bacteria } & \multicolumn{2}{|c|}{ S. dysenteriae } & \multicolumn{3}{|c|}{ E. coli } & \multicolumn{3}{|c|}{ S. aureus } & \multicolumn{3}{|c|}{ S. epidermidis } \\
\hline & Primers & a & b & c & a & b & c & a & b & c & a & b & c \\
\hline Control & & 5 & 8 & 2 & 6 & 3 & 2 & 5 & 4 & 4 & 2 & 4 & 4 \\
\hline Treated & & 5 & 4 & 4 & 5 & 3 & 2 & 3 & 3 & 1 & 6 & 2 & 2 \\
\hline \multicolumn{2}{|c|}{$\begin{array}{l}\text { MonomorphicNo. } \\
(\%)\end{array}$} & $10(100)$ & $2(16.6)$ & $0(0.0)$ & $6(54.5)$ & $6(100)$ & $0(0.0)$ & $4(50.0)$ & $4(57.2)$ & $0(0.0)$ & $2(25.0)$ & $0(0.0)$ & $0(0.0)$ \\
\hline \multicolumn{2}{|c|}{$\begin{array}{l}\text { Polymorphic No. } \\
(\%)\end{array}$} & $0(0.0)$ & $10(83.3)$ & $6(100)$ & $5(45.5)$ & $0(0.0)$ & $4(100)$ & $4(50.0)$ & $3(42.8)$ & $5(100)$ & $6(57.0)$ & $6(100)$ & $6(100)$ \\
\hline Total No. & & 10 & 12 & 6 & 11 & 6 & 4 & 8 & 7 & 5 & 8 & 6 & 6 \\
\hline
\end{tabular}



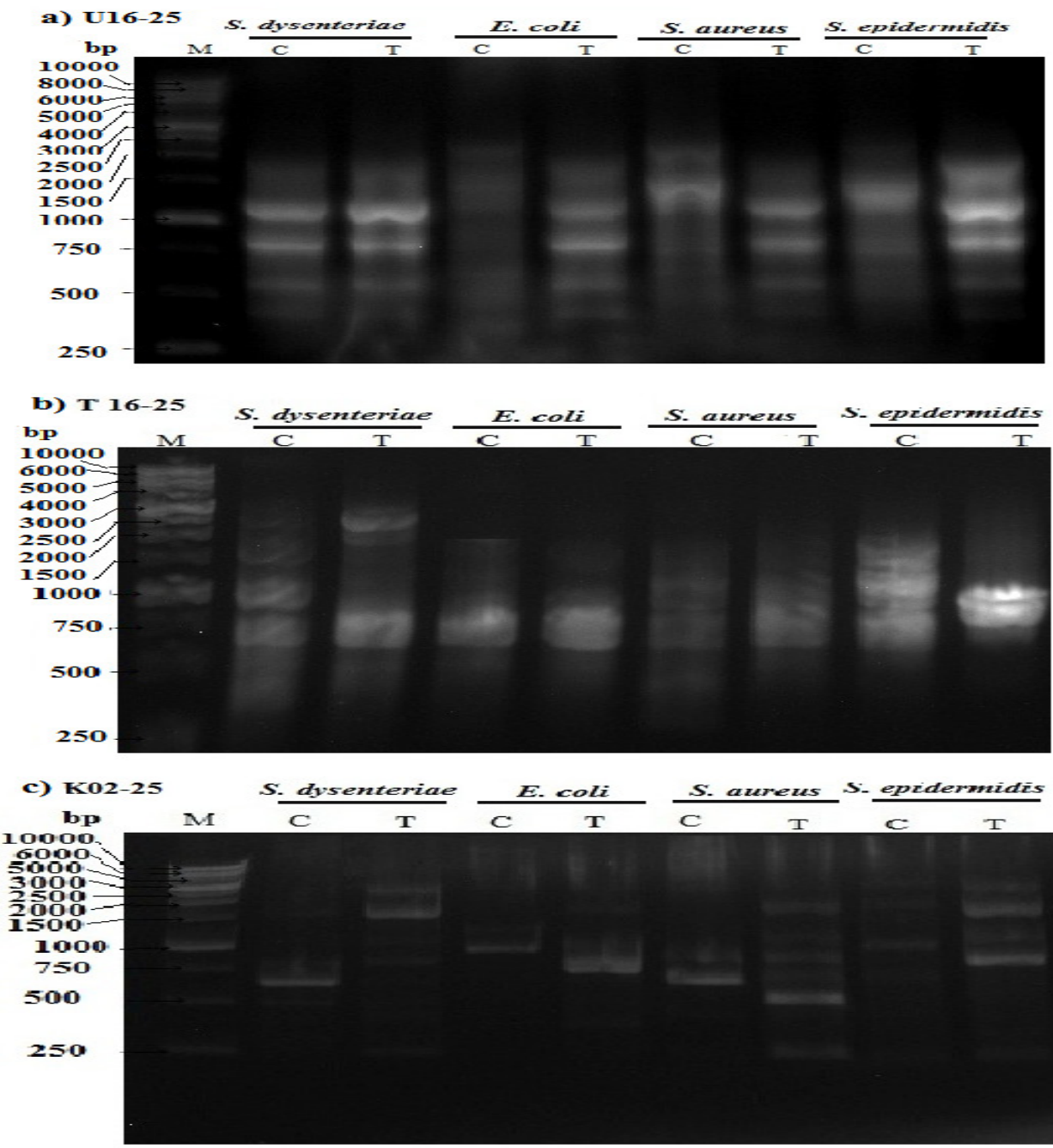

Fig. 5. RPAD-PCR of tested bacteria using three DNA-primers; a) U16-25, b) T16-25 and c) K02-25 RAPD-primers. (M): 1 Kb DNA ladder.bp= base pair, $M=$ marker, $C=$ control, $T=$ treated with ginger methanol extract.

\section{Discussion}

Treatment with antibiotics is not only expensive, but the risk of bacterial resistance to antimicrobial agents and side effects such as acidity burning sensation and damage to natural fauna of intestine are also involved. In this study, from the six types of ginger extracts only GiM extract recorded the highest antimicrobial activity with MIC $(0.7 \mathrm{mg} /$ $\mathrm{ml}$ ) against $S$. dysenteriae, E. coli, $S$. aureus and $S$. epidermidis where Gram positive bacteria were more affected than Gram negative bacteria. Arshad \& Shadab (2017) reported that methanol extract has better potential than hexane. Generally, different plant extracts differ in their anti-bacterial activities against different bacteria due to presence of different bioactive compounds. Also, different ginger extracts (distilled water, acetone, methanol and ethanol) have an antibacterial activity on $S$. aureus
(Noor et al., 2011). This matched with Kaushik \& Goyal (2011) who compared among water, ethanol, methanol, hexane and ethyl acetate ginger extracts against $E$. coli and $S$. aureus. This might be due to that GiM extract has different chemical constituents and secondary metabolites (Ghareeb et al., 2014). On the other hand, Sundar et al. (2015) found ethanol extract inhibited the growth of $E$. coli more than methanol extract. Also, ginger ethanol and methanol extracts were more active against Shigella spp., S. epidermidis, E. coli and S. aureus than ginger aqueous extracts (Gull et al., 2012). Depend on solubility of the active constituents, different extracts of spices or herbs differ in their anti-microbial activities against different bacteria and this might be due to the presence of different active phyto-compounds (Das, 2012).

Gram positive bacteria $S$. aureus and $S$. 
epidermidis showed more sensitivity to GiM extract besides lower growth rate pattern as compared with Gram negative bacteria $S$. dysenteriae and $E$. coli. The differences in growth pattern between Gram positive and Gram negative might be attributed to the dissimilarity of cell wall composition or the respiration pathway or the presence of some genes on the bacterial chromosome or plasmid that might be able to inactivate or degrade the active compounds in the GiM extract (Yang et al., 2000). Gram negative bacteria have an efficient permeability barrier, included of outer membrane, which limits the penetration of amphipathic compounds and multidrug resistance pumps that extrude toxins across this barrier. It is possible that the seeming ineffectiveness of plant antimicrobials is largely due to the permeability barrier (Tegos et al., 2002). Phytochemical analysis of GiM extract contained terpenoids, glycosides, flavonoids, alkaloids compounds, tannins, and saponins (Yadav \& Agarwala, 2011). Steriods are antibacterial compounds (Raquel, 2007), flavonoids, wide range antimicrobial agents, able to complex with bacterial cell wall (Cowan, 1999). The major compounds in ginger constitutes were gingerol, cis-6-shagol and zingerone and these matched with Arshad \& Shadab (2017).

The combination of GiM extract improved the efficiency of the gentamycin antibiotic more than the combination with the amoxicillin antibiotic, which is going parallel with Aburjai et al. (2001). In another study, the combination of methanol ginger extract and tetracycline antibiotic against S. aureus was synergistic (Betoni et al., 2006). Also, Jouda et al. (2015) found synergistic effect between methanol extracts of Artemisia herbaalba, Lantana camara, Allium sativum and Eucalyptus camaldulensis and gentamicin against $S$. aureus and E. coli. In previous researches, a synergism of various plant extracts and antibiotics against some pathogenic bacteria was noticed (Betoni et al., 2006 and Shaaban et al., 2013).

The biomarker assay detecting the protein changes based on SDS-PAGE profile and the genetic changes based on RAPD-PCR manipulation of GiM extract manifested a polymorphic pattern when comparing between the treated and untreated bacteria. This genetic changes represented in disappearance of some bands verify the capacity of GiM extract compounds such as tannins and alkaloids to generate some kind of mutation or genetic disorder or at least one nucleotide change (point mutation) which disturb the gene expression as well as the DNA and protein synthesis (Owen \& Johns, 1999 and Gilani et al., 2006). In conclusion, GiM extract has effective and safe bioactive antimicrobial agents against Gram negative and Gram positive bacteria. Also GiM extract increased the activity of gentamycin and amoxicillin antibiotics.

Acknowledgement: This work was financially supported by the Ministry of High Education (Libya).

\section{$\underline{\text { References }}$}

Abiramasundari, P., Priya, V., Jeyanthi, G.P. and Gayathri, D. (2011) Evaluation of the antibacterial activity of Cocculus hirsutus.Journal Drugs Medicines, 3, 26-31.

Aburjai, T., Darwish, R.M., Al-Khalil, S., Mahafzah, A. and Al-Abbadi, A. (2001) Screening of antibiotic resistant inhibitors from local plant materials against two different strains of Pseudomonas aeruginosa. Journal of Ethnopharmacology, 76(1), 39-44.

Arshad, M. and Shadab, M. (2017) Zingiber officinale extract: Antimicrobial properties phytochemical screening, drug likeness and physicochemical studies. European Journal of Pharmaceutical and Medical Research, 4(3), 364-368.

Bellik, Y. (2014) Total antioxidant activity and antimicrobial potency of the essential oil and oleoresin of Zingiber officinale Roscoe. Asian Pacific Journal of Tropical Disease, 4(1), 40-44.

Betoni, J.E.C., Mantovani, R.P., Barbosa, L.N., Di Stasi, L.C. and Fernandes Junior, A. (2006) Synergism between plant extract and antimicrobial drugs used on Staphylococcus aureus diseases. Memorias do Instituto Oswaldo Cruz, 101(4), 387-390.

Bhargava, S., Dhabhai, K., Batra, A., Sharma, A. and Malhotra, B. (2012) Zingiber officinale: Chemical and phytochemical screening and evaluation of its antimicrobial activities. Journal of Chemical and Pharmaceutical Research, 4(1), 360-364.

Cowan, M.M. (1999) Plant products as antimicrobial agents. Clinical Microbiology Reviews, 12(4), 564582.

Das, S., Anjeza, C. and Mandal, S. (2012) Synergistic or additive antimicrobial activities of Indian spice and herbal extracts against pathogenic, probiotic and food-spoiler micro-organisms. International Food Research Journal, 19(5), 1185-1191.

Egypt. J. Bot. Vol. 58 , No.1 (2018) 
Elazomi, A., Rahman, M.E., Liddell, S., Lovell, M. and Barrow, P. (2016) Determination of the proteins of Salmonella enteritidis involved in colonization of the chicken ceca using protein analysis. Imperial Journal of Interdisciplinary Research, 2(5), 17291738.

Ghareeb, M.A., Shoebl, H.A., Madkou, H.M.F., Refaey, L.A., Mohamed, M.A. and Saad, A.M. (2014) Antioxidant and cytotoxic activity of Tectona grandis Linn leaves. International Journal of Phytophamacology, 5(2), 143-157.

Gilani, S.A., Kikuchi, A., Shinwari, Z.K., Khattak, Z.I. and Watanab, K.N. (2006) Phytochemical, pharmacological and ethanotanical studies of Rhazya stricta Decne. Phytotherapy Research, 21, 301-307.

Gull, I., Saeed, M., Shaukat, H., Aslam, S.M., Samra, Z.Q. and Athar, A.M. (2012) Inhibitory effect of Allium sativum and Zingiber officinale extracts on clinically important drug resistant pathogenic bacteria. Annals of Clinical Microbiology and Antimicrobials, 11 (1), 8-11

Gupta, S. and Ravishankar, S. (2005) A comparison of the antimicrobial activity of garlic, ginger, carrot, and turmeric pastes against Escherichia coli O157: H7 in laboratory buffer and ground beef. Foodborne Pathogens and Disease, 2(4), 330-340.

Habib, S.H.M., Makpol, S., Hamid, N.A.A., Das, S., Ngah, W.Z.W. and Yusof, Y.A.M. (2008) Ginger extract (Zingiber officinale) has anti-cancer and antiinflammatory effects on ethionine-induced hepatoma rats. Clinics, 63(6), 807-813.

Hudzicki, J. (2009) Kirby-Bauer disk diffusion susceptibility test protocol. American Society for Microbiol. 1-23.

Jouda, M.M., Elbashiti, T., Masad, A. and Albayoumi, M. (2015) The antibacterial effect of some medicinal plant extracts and their synergistic effect with antibiotics. Research Article, 5(2), 23-33.

Kaushik, P. and Goyal, P. (2011) Evaluation of various crude extracts of Zingiber officinale rhizome for potential antibacterial activity: A study in vitro. Advances in Microbiology, 1(1),7-12.

Laemmli, U.K. (1970) Cleavage of structural proteins during the assembly of the head of bacteriophage T4. Nature, 227, 680-685.

Lawal, D., Burgess, C., McCabe, E., Whyte, P. and Duffy, G. (2015) Development of a quantitative real time PCR assay to detect and enumerate Escherichia coli $\mathrm{O} 157$ and $\mathrm{O} 26$ serogroups in bovine recto-anal swabs. Journal of Microbiological Methods, 114, 9-15.

Nazari, A., Fanaei, H., Dehpour, A.R., Hassanzadeh, G., Jafari, M., Salehi, M. and Mohammadi, M. (2015) Chemical composition and hepatoprotective activity of ethanolic root extract of Taraxacum syriacum Boiss against acetaminophen intoxication in rats. Bratislavske Lekarske Listy, 116(1), 41-46.

Noor, A.A., Memon, A.G. and Sherwani, S.K. (2011) Dose response curve of plants extracts against the human pathogens. Gomal University Journal of Research, 27(2), 1-17.

Owen, P.L. and Johns, T. (1999) Xanthine oxidase inhibitory activity of northeastern North American plant remedies used for gout. Journal of Ethnopharmacology, 64(2), 149-160.

Park, M., Bae, J. and Lee, D.S. (2008) Antibacterial activity of [10]-gingerol and [12]-gingerol isolated from ginger rhizome against periodontal bacteria. Phytotherapy Research: PTR, 22(11), 1446-1449.

Pattaratanawadee, E., Rachtanapun, C., Wanchaitanawong, P. and Mahakarnchanakul, W. (2006) Antimicrobial activity of spice extracts against pathogenic and spoilage microorganisms. Kasetsart Journal National Science, 40,159-165.

Raquel, F.E. (2007) Bacterial lipid composition and antimicrobial efficacy of cationic steroid compounds. Biochemica et Biophysica Acta, 4(1), 2500-2509.

Shaaban, H., Ahmed, M., Sideek, L. and Amer, M. (2013) Study on the antimicrobial activity and synergistic/ antagonistic effect of interactions between antibiotics and some spice essential oils against pathogenic and food-spoiler microorganisms. Journal of Applied Sciences Research, 9(8), 5076-5085.

Sundar, S., Jayasree, T., Ditya, D., Sanjana, J., Sowmya, M. and Jahnavi, S. (2015) Antimicrobial activity of aminoglycoside antibiotics combined with clove and ginger. World Journal of Pharmacy and Pharmaceutical Sciences, 4(6), 1515-1524.

Tegos, G., Stermitz, S.R., Lomovskaya, O. and Lewis, K. (2002) Multidrug pump inhibitions uncover remarkable activity of plant antimicrobials. Antimicobial Agents Chemotherapy, 46(10), 31-33.

Wang, C.C., Chen, L.G., Lee, L.T. and Yang, L.L. (2002) Effects of 6-gingerol, an antioxidant from ginger, on inducing apoptosis in human leukemic HL-60 cells. Journal: "In Vivo", 17(6), 641-645. 
Wei, Q.Y., Ma, J.P., Cai, Y.J., Yang, L. and Liu, Z.L. (2005) Cytotoxic and apoptotic activities of diarylheptanoids and gingerol-related compounds from the rhizome of Chinese ginger. Journal of Ethnopharmacology, 102(2), 177-184.

Wichtl, M. (2004) "Herbal Drugs and |Phytopharmaceuticals: A Handbook for Practice on a Scientific Basis". $3^{\text {rd }}$ ed. Medpharm Scintific Publisher.
Yadav, R. and Agarwala, M. (2011) Phytochemical analysis of some medicinal plants. Journal of Phytology, 3(12), 10-14.

Yang, S., Yu, J. and Xu, L. (2000) Chemical constituents of annonaceae plants and their antitumor activities. Zhongguo Yi Xue Ke Xue Yuan Xие Bao. 22(4), 376-82https://www.ncbi.nlm.nih. gov/pubmed/12903455.

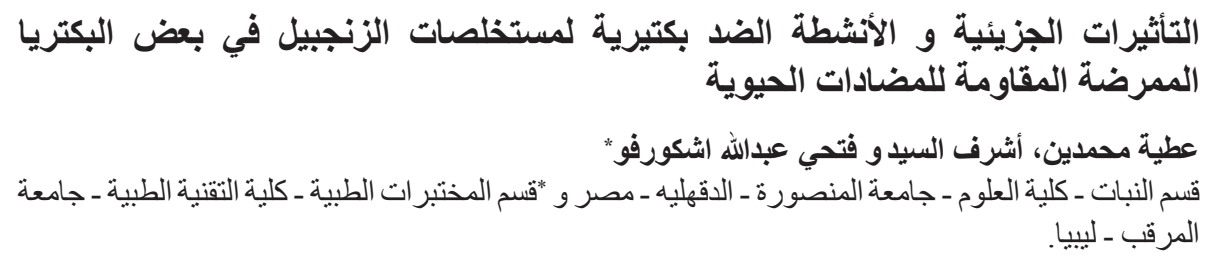

في هذه الدر اسة تم تقييم النشاط الضد بكتيري لستة أنواع من مستخلصات الزنجبيل ضد ضد أربعة انواع من البكتريا

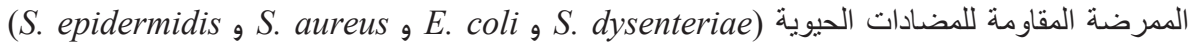

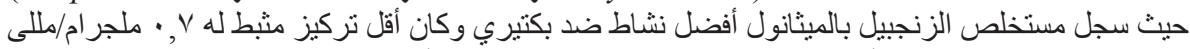

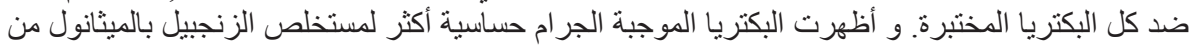

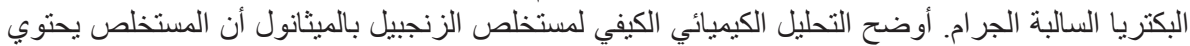
على Alkaloids و و التي لها معدلات تأثير و واسعة كمضادات للبكتيريا. كما أظهر منظار التحليل

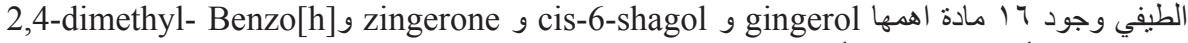

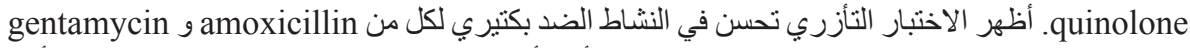

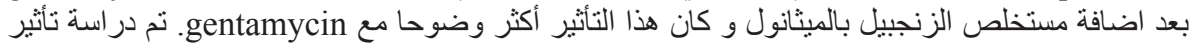

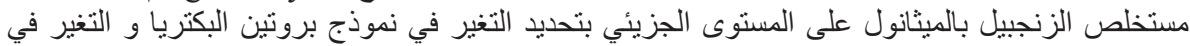

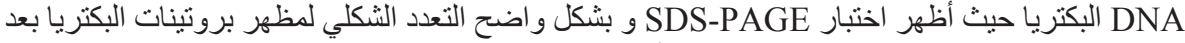

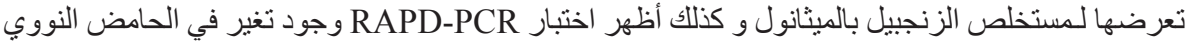

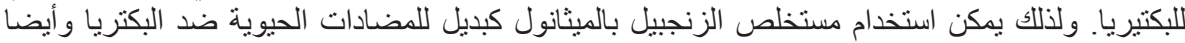
كمدعم للمضادات الحيوية التي تلاقي مقاو مة من البكتريا. 